Jurnal Ekonomi dan Industri

e-ISSN: $2656-3169$

Volume 22, No.2, Mei-Agustus 2021

p- ISSN: 0853-5248

\title{
PENGARUH KUALITAS LAYANAN DAN HARGA TERHADAP MINAT BELI ULANG PELANGGAN PT SAKYO PUTRA PRATAMA
}

\author{
Dwi Anggraeni 1) \\ 1) Mahasiswa Program Studi Manajemen FE UNKRIS \\ Amanda Setiorini ${ }^{2)}$ \\ 2) Dosen Program Studi Manajemen FE UNKRIS \\ Alamat: Kampus UNKRIS, Jatiwaringin Jakarta Timur \\ Email: amanda.unkris@setiorini.net
}

\begin{abstract}
This study aims to identify the effect of service quality and price on the repurchase of merchandise at PT Sakyo Putra Pratama, using quantitative descriptive research. The analytical method used is multiple linear regression analysis. The results showed that service quality and price simultaneously have a positive and direct impact to repurchasing the merchandise. The calculation of the correlation coefficient and determination coefficient indicate that there is a very close level of relationship between the variabels of service quality and price towards repurchasing at PT Sakyo Putra Pratama.
\end{abstract}

Keywords: service quality, price, repurchase

\section{PENDAHULUAN}

Saat ini persaingan semakin ketat, produk serta harga yang ditawarkan kepada konsumen sudah saling mendekati dan perusahaan dituntut untuk dapat memenangkan persaingan dengan cara mempertahankan konsumen. Kunci sukses perusahaan untuk memenangkan persaingan adalah dengan memberikan pelayanan yang berkualitas secara konsisten. Konsumen akan selalu menuntut kepuasan atas produk yang telah mereka beli karena telah mengeluarkan biaya untuk mendapatkannya.

Untuk memajukan perusahaan di masa depan, perusahaan harus terus mempertahankan kerja sama yang saling menguntungkan dengan konsumennya. Dan, keterlibatan karyawan sangat penting terhadap kualitas layanan, karena jika karyawan memberikan layanan berkualitas, maka konsumen akan merasa puas dan akan terus bertahan menggunakan produk perusahaan tersebut.

PT Sakyo Putra Pratama merupakan sub-distributor yang mengambil produk dari distributor agar terjadi pemerataan produk dari produsen (principal) kepada konsumen Kualitas layanan PT Sakyo Putra Pratama cukup baik, dengan menciptakan program one day service dimana semua pesanan diantar tidak lebih dari 24 jam. Hal ini menjadi nilai tambah untuk bersaing dengan pedagang besar farmasi lainnya. Selain kualitas layanan, ada pula komponen harga yang juga dapat mempengaruhi minat beli ulang dan merupakan salah satu unsur penting untuk menentukan pangsa pasar dan meningkatkan keuntungan perusahaan.

\section{LANDASAN TEORI}

\section{Kualitas Layanan}

Menurut Kotler (2016) layanan merupakan setiap tindakan atau kegiatan yang dapat ditawarkan oleh satu pihak kepada pihak lain, pada dasarnya tidak berwujud dan tidak mengakibatkan kepemilikan apapun, sedangkan menurut Mahmoedin (2010) layanan adalah

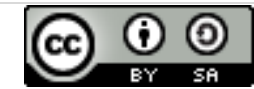


serangkaian kegiatan yang bersifat tidak kasat mata yang terjadi karena adanya interaksi antara konsumen dengan karyawan.

Indikator kualitas layanan terdiri atas bukti fisik (tangibles), keandalan (reliability), daya tanggap (responsiveness), jaminan (assurance), dan empati (emphaty) (Parasuraman dalam Lupiyoadi, 2013).

\section{Harga}

Tjiptono (2011) menyatakan bahwa harga yang terjangkau akan lebih meningkatkan keinginan konsumen untuk membeli produk yang ditawarkan. Selain itu, harga yang dapat dijangkau oleh konsumen memiliki peran pada persepsi pembelian, yaitu pengorbanan, nilai, dan keinginan untuk membeli. Kotler dan Amstrong (2016) menyatakan bahwa harga merupakan sejumlah uang yang dikeluarkan untuk sebuah produk atau jasa, atau sejumlah nilai yang ditukarkan oleh konsumen untuk memperoleh manfaat atau kepemilikan atau penggunaan atas sebuah produk atau jasa.

Indikator harga terdiri atas keterjangkaun harga oleh konsumen, kesesuaian harga dengan kualitas produk, kesesuaian harga dengan manfaat, dan kesesuaian harga dengan kemampuan atau daya saing (Kotler dan Amstrong, 2016).

\section{Pembelian Ulang}

Pembelian ulang menurut Peter dan Olson (2010) adalah kegiatan pembelian yang dilakukan lebih dari satu kali atau beberapa kali, sedangkan menurut Kotler, et al (2014), minat beli timbul setelah adanya proses evaluasi alternatif. Dalam proses evaluasi, seseorang akan membuat suatu rangkaian pilihan mengenai produk yang hendak dibeli atas dasar merek maupun minat. Kepuasan yang diperoleh seorang pelanggan, dapat mendorong seseorang untuk melakukan pembelian ulang, menjadi loyal terhadap produk tersebut ataupun loyal terhadap toko tempat dia membeli barang tersebut, sehingga pelanggan dapat menceritakan hal-hal yang baik kepada orang lain.

Indikator pembelian ulang terdiri atas perhatian (attention), ketertarikan (interest), keinginan (desire), dan keyakinan (conviction) (Lucas \& Britt, 2012).

\section{METODE PENELITIAN}

\section{Rancangan Penelitian}

Tujuan penelitian ini adalah untuk menganalisis hubungan kausalitas antara kualitas layanan dan harga dengan pembelian ulang, melalui pengumpulan data primer dengan penyebaran kuesioner. Skala yang digunakan dalam kuesioner ini adalah Skala diferensial semantik, yang merupakan pengukuran terhadap kecocokan dengan skala jawaban berjenjang, dimana setiap jawaban bisa diberi bobot sesuai dengan intensitasnya.

\section{Metode Pengumpulan Data}

\section{Sumber data}

Sumber data yang digunakan adalah data primer. Data primer adalah data yang mengacu pada informasi yang diperoleh langsung oleh peneliti terkait dengan variabel yang akan menjadi inti dalam penelitian. Dengan kata lain, data primer adalah sumber data yang langsung memberikan data kepada pengumpul data (Sugiyono, 2014). Data primer dalam penelitian ini merupakan hasil dari penyebaran kuesioner pada sampel yang telah ditentukan, 
berupa jawaban-jawaban yang diberikan oleh responden atas pernyataan yang terdapat dalam kuesioner.

Dalam penelitian ini, data dikumpulkan dengan menggunakan metode survei, yaitu dengan menyebarkan angket kepada sampel yang akan diteliti. Dalam penelitian ini digunakan skala semantik diferensial 1-7 untuk mendapatkan data yang bersifat interval. dengan urutan skala 1 menunjukkan bahwa responden sangat tidak setuju terhadap pernyataan yang diberikan, sedangkan angka 7 menunjukkan bahwa responden sangat setuju terhadap pernyataan yang diberikan. Kuesioner dalam penelitian ini dibagikan kepada konsumen PT Sakyo Putra Pratama.

\section{Populasi dan sampel}

Populasi adalah wilayah generalisasi yang terdiri atas obyek atau subyek yang mempunyai kualitas dan karakteristik tertentu yang ditetapkan oleh peneliti untuk dipelajari dan kemudian ditarik kesimpulannya (Sugiyono, 2014). Populasi dalam penelitian ini adalah seluruh konsumen PT Sakyo Putra Pratama dengan karakteristik sebagai berikut: a). Konsumen yang berada di Bekasi. b). Telah menjadi pelanggan setia yang aktif sejak 2 tahun berturut-turut

Dari total konsumen, ditemukan ada 50 konsumen yang masuk ke dalam karakteristik tersebut. Dengan demikian, populasi pada penelitian ini adalah 50. Sampel adalah bagian dari jumlah dan karakteristik yang dimiliki oleh populasi tersebut. Dalam penentuan jumlah sampel yang akan diolah dari jumlah populasi, maka harus dilakukan dengan teknik pengambilan sampel yang tepat. Dalam penelitian ini, peneliti menggunakan teknik purposive sampling dimana sampel ditentukan sendiri oleh peneliti sesuai dengan karakteristik yang telah ditentukan. Untuk keakuratan penelitian, digunakan tabel yang disusun oleh Isaac dan Michael dalam Sugiyono (2014) dengan taraf kesalahan 5\%. Pada penelitian ini, sampel yang digunakan sebanyak 44.

\section{Teknik Analisis Data}

Teknik analisis data yang digunakan dalam penelitian ini adalah analisis regresi linear sederhana dan berganda, yaitu sebagai berikut:

$$
\begin{array}{r}
Y=\alpha_{1}+\beta_{1} X_{1} \ldots \\
Y=\alpha_{2}+\beta_{2} X_{2} \ldots \\
Y=\alpha_{3}+\beta_{1} X_{1}+\beta_{2} X_{2}
\end{array}
$$

dimana:

$$
\begin{aligned}
& \mathrm{Y}=\text { Minat Beli Ulang } \\
& \mathrm{X}_{1}=\text { Kualitas Layanan } \\
& \mathrm{X}_{2}=\text { Harga } \\
& \alpha_{\mathrm{i}}=\text { Konstanta }(\mathrm{i}=1,2,3) \\
& \beta_{\mathrm{i}}=\text { Koefisien regresi }(\mathrm{i}=1,2)
\end{aligned}
$$




\section{HASIL PENELITIAN DAN PEMBAHASAN}

\section{Hasil Penelitian}

\section{Uji validitas}

Uji validitas digunakan untuk mengetahui valid atau tidaknya suatu draf isian, jika nilai r-hitung lebih besar dari r-tabel dan nilainya positif, maka butir pernyataan tersebut dikatakan valid (Ghozali, 2013). $r_{\text {tabel }}$ dengan tingkat probabilitas 0,05 adalah 0,297.

Hasil penghitungan menunjukkan bahwa sepuluh butir pertanyaan untuk variabel Kualitas Layanan, delapan butir pertanyaan untuk variabel Harga, dan delapan butir pertanyaan untuk variabel Minat Beli Ulang, seluruhnya memiliki nilai lebih besar daripada nilai $r_{\text {tabel, }}$ yaitu 0,297. Maka dapat disimpulkan bahwa semua butir pertanyaan adalah valid.

\section{Uji realibilitas}

Uji reliabilitas dilakukan untuk mengetahui sejauh mana konsistensi instrumen penelitian. Suatu instrumen penelitian dapat dikatakan reliabel atau konsistensi jika memiliki nilai Cronbach Alpha > 0,6. Hasil uji reliabilitas untuk variabel Kualitas Layanan adalah 0,903, untuk variabel Harga adalah 0,865, dan untuk variabel Minat Beli Ulang adalah 0,750. Hal ini menunjukkan bahwa setiap butir pernyataan yang digunakan sebagai instrumen penelitian mampu memperoleh data yang konsisten (reliabel), yang berarti bila pernyataan tersebut diajukan kembali akan diperoleh jawaban yang relatif sama dengan jawaban sebelumnya.

\section{Analisis regresi linear berganda}

Tabel 1: Pengaruh Kualitas Layanan dan Harga Terhadap Minat Beli Ulang Pelanggan PT Sakyo Putra Pratama

\begin{tabular}{lccccc}
\hline \multirow{1}{*}{ Variabel } & \multicolumn{5}{c}{ Parameter } \\
\cline { 2 - 6 } & $\begin{array}{c}\text { Mult. } \\
\text { R }\end{array}$ & $\begin{array}{c}\text { R } \\
\text { Square }\end{array}$ & Konstanta & $\begin{array}{c}\text { Koefisien } \\
\text { Regresi }\end{array}$ & Sig. \\
\hline Kualitas Layanan & 0,847 & 0,718 & 12,595 & 0,305 & 0,000 \\
Harga & & & & 0,250 & 0,000 \\
\hline Pengujian Signifikan & & & & \\
\hline F hitung $=7,478$ & & &
\end{tabular}

Keterangan: Variabel Minat_Beli_Ulang

Sumber: data diolah 2021

Berdasarkan Tabel 1, nilai $\mathrm{F}$ hitung sebesar 7,478 atau dengan melihat signifikan probabiliti dengan tingkat kepercayaan 0,05. Berdasarkan perhitungan tersebut dapat dinyatakan bahwa nilai F hitung = 7,478 atau dengan signifikansi probabiliti 0,00 lebih kecil dari alpha 0,05, maka Ho tolak, Ha terima artinya secara bersama-sama kualitas layanan dan harga berpengaruh signifikan pada tingkat nyata $99 \%$ terhadap minat beli ulang pelanggan PT Sakyo Putra Pratama. Nilai Koefisien Determinasi $\left(\mathrm{R}^{2}\right)$ sebesar 0.718, artinya kualitas layanan dan harga secara bersama-sama memberikan kontribusi sebesar 71,8\% kepada minat beli ulang pelanggan PT Sakyo Putra Pratama, sedangkan sisanya sebesar 28,2\% disumbangkan faktor lain yang tidak dibahas dalam penelitian ini. 
Persamaan Regresi $\mathrm{Y}=12,595+0,305\left(\mathrm{X}_{1}\right)+0,250\left(\mathrm{X}_{2}\right)$

Kualitas layanan dan harga berpengaruh positif dan signifikan terhadap minat beli ulang pelanggan PT Sakyo Putra Pratama pada tingkat nyata 99\%. Koefisien kualitas layanan sebesar 0,305, artinya jika ada peningkatan kualitas layanan, maka minat beli ulang pelanggan PT Sakyo Putra Pratama akan meningkat dengan asumsi harga tidak berubah. Koefisien harga sebesar 0,250, artinya jika ada peningkatan harga, maka minat beli ulang pelanggan PT Sakyo Putra Pratama akan meningkat, dengan asumsi kualitas layanan tidak berubah.

\section{Analisis regresi linear sederhana}

Tabel 2: Pengaruh Kualitas Layanan Terhadap Minat Beli Ulang Pelanggan PT Sakyo Putra Pratama

\begin{tabular}{lcccccc}
\hline \multirow{2}{*}{ Variabel } & $\mathbf{R}$ & $\begin{array}{c}\text { R } \\
\text { Square }\end{array}$ & $\begin{array}{c}\text { Kons } \\
\text { tanta }\end{array}$ & $\begin{array}{c}\text { Koefisien } \\
\text { Regresi }\end{array}$ & Sig & $\boldsymbol{\alpha}$ \\
\hline Kualitas_Layanan & 0,424 & 0,179 & 20,772 & 0,295 & 0,04 & 0,05 \\
\hline Pengujian Signifikan \\
\hline t hitung = 3,031 \\
\hline Keterangan: Variabel Minat_Beli_Ulang \\
Sumber: data diolah 2021
\end{tabular}

Tabel 2, nilai koefisien determinasi $\left(\mathrm{R}^{2}\right)$ sebesar 0.179 , artinya kualitas layanan memberikan kontribusi sebesar 17,9\% kepada minat beli ulang pelanggan PT Sakyo Putra Pratama, sedangkan sisanya sebesar $82,1 \%$ disumbangkan faktor lain yang tidak diteliti.

$$
\text { Persamaan Regresi } \mathrm{Y}=20,772+0,295\left(\mathrm{X}_{1}\right)
$$

Kualitas layanan berpengaruh positif dan signifikan pada tingkat nyata 95\% terhadap minat beli ulang pelanggan PT Sakyo Putra Pratama. Koefisien kualitas layanan sebesar 0,295, artinya jika ada peningkatan kualitas layanan, maka minat beli ulang pelanggan PT Sakyo Putra Pratama akan meningkat.

Untuk menguji hubungan kualitas layanan kerja terhadap minat beli ulang pelanggan PT Sakyo Putra Pratama signifikan atau tidak, dilakukan pengujian t hitung atau dengan menggunakan probabilitas signifikan dengan tingkat kepercayaan. Berdasarkan perhitungan tersebut dapat dinyatakan bahwa nilai t hitung $=11,967$ atau signifikansi probabilitas 0,04 lebih kecil dari alpha 0,05, maka Ho tolak, Ha terima, diartikan terdapat pengaruh signifikan kualitas layanan terhadap minat beli ulang pelanggan PT Sakyo Putra Pratama.

Tabel 3: Pengaruh Harga Terhadap Minat Beli Ulang Pelanggan PT Sakyo Putra Pratama

\begin{tabular}{lcccccc}
\hline & \multicolumn{7}{c}{ Parameter } \\
\cline { 2 - 7 } Variabel & $\mathbf{R}$ & $\begin{array}{c}\mathbf{R} \\
\text { Square }\end{array}$ & $\begin{array}{c}\text { Kons } \\
\text { tanta }\end{array}$ & $\begin{array}{c}\text { Koefisien } \\
\text { Regresi }\end{array}$ & Sig & $\boldsymbol{\alpha}$ \\
\hline Harga & 0,272 & 0,074 & 26,637 & 0,229 & 0,074 & 0,05 \\
\hline Pengujian Signifikan \\
\hline
\end{tabular}


Sumber: data diolah 2021

Tabel 3, nilai koefisien determinasi $\left(\mathrm{R}^{2}\right)$ sebesar 0.074 , artinya harga memberikan kontribusi sebesar 7,4\% kepada minat beli ulang pelanggan PT Sakyo Putra Pratama, sedangkan sisanya sebesar $92,6 \%$ disumbangkan faktor lain yang tidak diteliti.

$$
\text { Persamaan Regresi } \mathrm{Y}=26,637+0,229\left(\mathrm{X}_{2}\right)
$$

Harga berpengaruh positif dan tidak signifikan pada tingkat nyata 95\% terhadap minat beli ulang pelanggan PT Sakyo Putra Pratama. Koefisien harga sebesar 0,229, artinya jika ada peningkatan harga, maka minat beli ulang pelanggan PT Sakyo Putra Pratama akan meningkat.

Untuk menguji hubungan harga terhadap minat beli ulang pelanggan PT Sakyo Putra Pratama signifikan atau tidak, dilakukan pengujian t hitung atau dengan menggunakan probabilitas signifikan dengan tingkat kepercayaan. Berdasarkan perhitungan tersebut dapat dinyatakan bahwa nilai t hitung $=1,833$ atau signifikansi probabilitas 0,074 lebih besar dari alpha 0,05, maka Ho terima, Ha tolak, artinya bahwa harga tidak berpengaruh signifikan terhadap minat beli ulang pelanggan PT Sakyo Putra Pratama.

\section{Pembahasan}

\section{Pengaruh kualitas layanan dan harga terhadap minat beli ulang pelanggan PT Sakyo Putra Pratama.}

Hasil penelitian menunjukkan bahwa hipotesis ini diterima. Ini berarti peningkatan kualitas layanan dan kesesuaian harga dapat meningkatkan minat beli ulang pelanggan PT Sakyo Putra Pratama. Tingginya pengaruh kualitas layanan terhadap minat beli ulang karena PT Sakyo Putra Pratama telah memberikan kualitas layanan yang sangat baik seperti penampilan karyawan yang rapih, teknologi dan peralatan yang digunakan memberikan kemudahan untuk konsumen, karyawan cukup cepat tanggap dalam memenuhi permintaan konsumen selain itu karyawan memiliki empati dalam membantu konsumen. Hal-hal tersebut menunjukan layanan PT Sakyo Putra Pratama sudah memenuhi kelima dimensi kualitas layanan menurut Parasuraman (dalam Lupiyoadi 2013) tangibles (bukti fisik), reliability (keandalan), responsiveness (daya tanggap), assurance (jaminan), empathy (empati). Penelitian ini sesuai dengan hasil penelitian Aptaguna dan Pitaloka, yang menjelaskan ada pengaruh kualitas layanan dan harga terhadap minat beli.

\section{Pengaruh kualitas layanan terhadap minat beli ulang pelanggan PT Sakyo Putra Pratama.}

Hasil penelitian menunjukkan bahwa hipotesis ini diterima. Nurhayati dan Murti (2012) menyebutkan bahwa minat pembelian ulang adalah tindakan konsumen untuk membeli kembali suatu produk yang disebabkan adanya kepuasan yang diterima sesuai dengan yang dinginkan konsumen. Minat beli konsumen adalah tahap dimana konsumen membentuk pilihan diantara beberapa merk yang tergabung dalam perangkat pilihan. Kemudian pada akhirnya melakukan suatu pembelian pada suatu alternatif yang paling disukainya atau proses yang dilalui konsumen untuk membeli suatu produk yang didasari oleh macam-macam pertimbangan seperti kualitas layanan dan harga. Melalui proses evaluatif ini tampaknya pelanggan PT Sakyo Putra Pratama menganggap bahwa kualitas layanan yang diberikan telah sesuai dengan ekspektasi dan kebutuhan mereka. Hal ini sesuai dengan penelitian terdahulu Marieta dan Prilando. Pengaruh kualitas layanan terhadap minat

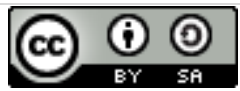


beli ulang studi kasus Legend Coffee Yogyakarta. Hasil analisis penelitian ini menunjukkan bahwa kualitas layanan di Coffee Legend berpengaruh positif pada minat beli ulang, semakin baik kualitas layanan yang diberikan maka akan semakin tinggi pula kepuasan konsumennya dan menimbulkan minat beli ulang. Menurut Kasmir (2017) kualitas pelayanan didefinisikan sebagai tindakan yang bertujuan untuk memberikan kepuasan kepada konsumen.

\section{Pengaruh harga terhadap minat beli ulang pelanggan PT Sakyo Putra Pratama.}

Hasil penelitian menunjukan bahwa hipotesis ini ditolak. Harga merupakan bauran pemasaran yang paling fleksibel, dan dapat menunjukkan kualitas suatu produk. Kotler \& Amstrong (2016) menyatakan bahwa harga merupakan sejumlah uang yang dikeluarkan untuk sebuah produk atau jasa, atau sejumlah nilai yang ditukarkan oleh konsumen untuk memperoleh manfaat, kepemilikan atau penggunaan atas sebuah produk atau jasa. Hasil penelitian ini relevan dengan penelitian sebelumnya yang dilakukan oleh. Faradiba, Sri Rahayu Tri Astuti yang berujudul Analisis Pengaruh Kualitas Produk, Harga, Lokasi, dan Kualitas Pelayanan Terhadap Minat Beli Ulang Konsumen Warung Makan Bebek Gendut Semarang. Hasil analisis penelitian ini menunjukkan bahwa variabel harga memiliki pengaruh positif terhadap minat beli ulang konsumen, tapi tidak signifikan.

\section{KESIMPULAN DAN SARAN}

\section{Kesimpulan}

Dari hasil penelitian yang telah dilakukan terhadap pelanggan PT Sakyo Putra Pratama dapat disimpulkan sebagai berikut: 1). Kualitas layanan dan harga mendorong peningkatan minat beli ulang pelanggan PT Sakyo Putra Pratama. 2). Kualitas layanan mendorong peningkatan Minat Beli Ulang pelanggan pelanggan PT Sakyo Putra Pratama. 3). Harga mendorong peningkatan minat beli ulang pelanggan PT Sakyo Putra Pratama.

\section{Saran}

Berdasarkan hasil penelitian dan pembahasan perlu dipertimbangkan untuk memberikan rekomendasi atau saran yang dapat ditindaklanjuti oleh PT Sakyo Putra Pratama sebagai berikut: 1). Untuk meningkatkan kualitas layanan, PT Sakyo Putra Pratama dapat membuat call center dan memastikan ada keluhan dan pengaduan yang disampaikan melalu layanan tersebut ditindaklanjuti dengan baik. Cara lain untuk meningkatkan kualitas layanan juga dapat dilaukan dengan memberi pelatihan rutin kepada karyawan, agar ketrampilan mereka dalam menghadapi konsumen semakin tinggi. Hal ini dapat meningkatkan kualitas interaksi dengan konsumen dan mempertahankan kepuasan konsumen. 2). Terkait dengan harga, PT Sakyo Putra Pratama dapat memberikan potongan karena konsumen sangat menyukai potongan harga. Potongan harga yang memungkinkan dilakukan PT Sakyo Putra Pratama sebagai sub-distributor adalah menawarkan potongan harga tergantung dengan jumlah pengambilan produknya untuk produk-produk yang permintannya sedang mengalami peningkatan. Selain itu, dapat juga dilakukan dengan memberi free product untuk konsumen yang pembelian setiap bulannya mengalami peningkatan dalam rentang waktu tertentu. Hal ini akan penarik perhatian konsumen untuk semakin berinteraksi dengan PT Sakyo Putra Pratama.

\section{DAFTAR PUSTAKA}


Aptaguna, A dan Pitaloka, E, (2016), Pengaruh Kualitas Layanan dan Harga Terhadap Minat Beli Jasa Go-jek. Skripsi, Banten: Universitas Pembangunan Jaya.

Faradiba, Sri Rahayu Tri Astuti, (2013), Analisis Pengaruh Kualitas Produk, Harga, Lokasi, dan Kualitas Pelayanan Terhadap Minat Beli Ulang Konsumen di Warung Makan Bebek Gendut Semarang. Skripsi, Semarang: Universitas Diponegoro.

Ghozali, Imam. (2013), Aplikasi Analisis Multivariate dengan Program IBM SPSS 21 Update PLS Regresi. Semarang: Badan Penerbit Universitas Diponegoro.

Kasmir, (2017), Customer Service Excellent. Depok: PT Raja Grafindo Persada

Kotler, Philip and Gary Amstrong, (2016), Prinsip-prinsip Pemasaran. Edisi 13. Jilid 1. Jakarta: Erlangga

Lucas, D. B., \& Britt, S. H., (2012), Measuring Advertising Effectiveness. New York: McGrawHill.

Lupiyoadi, Rambat, (2013), Manajemen Pemasaran Jasa. Jakarta: Penerbit Salemba Empat Mahmoedin, (2010), Melacak Kredit Bermasalah, Jakarta: Pustaka Sinar Harapan.

Nurhayati dan W. W. Murti. (2012) Analisis Faktor-Faktor Yang Mempengaruhi Minat Beli Ulang Masyarakat Terhadap Produk Handphone. Journal of Value Added. Vol 8 No. 2, Maret-Agustus 2012. Hal. 47-62. ISSN (P): 1693-3435; ISSN (O): 2580-4863.

Paul J. Peter dan Jerry C. Olson, (2010), Consumer Behavior and Marketing Strategy, Ninth Edition. New York: McGraw-Hill Companies.

Prilando, Marieta Dewi, (2017), Pengaruh Kualitas Layanan Terhadap Minat Beli Ulang Studi Kasus Legend Coffee Yogyakarta. Skripsi, Yogyakarta: Universitas Sanata Darma Yogyakarta

Sugiyono, (2014), Metode Penelitian Kuantitatif, Kualitatif dan R\&D, Bandung: CV Alfabeta

Sugiyono, (2014), Statiska Untuk Penelitian, Bandung: Alfabeta

Tjiptono, Fandy, (2011), Strategi Pemasaran, Edisi 2, Yogyakarta: ANDI. 